\title{
工業デザイン系学科における卒研支援データベースの構成要件 ON CONSTITUENT FACTORS OF DATABASE SYSTEM FOR GRADUATION STUDY IN INDUSTRIAL DESIGN COURSE
}

\author{
下村康弘*, 寺井達夫** \\ Yasuhiro SHIMOMURA and Tatsuo TERAI
}

\begin{abstract}
A variety of graduation study subjects of the students in the industrial design course requires useful tools to assist their work, but few systems satisfy them of this matter. Such a system should deal with facility related information with relevant decisive attributes. This paper clarifies the major constituent factors of the database system to be developed through two questionnaires against faculty and undergraduate students on how they utilize these resources in their practical work. Major results of the investigation are confirmation of the necessity of the DBMS system and clarification of the main constituent factors of the database.
\end{abstract}

Keywords: graduation study, industrial design, database, framework, questionnaire 卒業研究、工業デザイン、データベース、枠組、アンケート

\section{1.はじめに}

現在、大学における教育研究活動のための作業環境は十分整備 されているとはいえない状況にある。組織構成が多様で、存在する 様々なモノや作業スペースを利用するうえで、所要情報が十分に把 握されず、活用されない場合も多い。それらの情報を把握できても、 教員ならびに大学院生以外のほほ全員が毎年入れ替わり、情報を効 果的に継承することが容易でないといった教育機関ゆえの特質が状 況をより複雑なものとしている。

この種の問題解決にはファシリティマネジメント(FM)手法が有 効であるとされている。しかし、規模の如何を問わず、大学への適 用事例はまだ少ないこと、オフィス等への適用例は報告されつつあ るが、奻果が具体的に検証された例は少なく、参照するに十分な成 果は得られていないことなどは、作業睘境改善には組織ごとの個別 的対応に委祃る心゙き部分が大きく、かつ基礎的研究の充足が要求さ れていることを示しているものであるということができる。

\section{2. 研究目的}

本研究は F M的観点のもとに大学における教育研究等の作業環 境の改善を図るための支援システムを椣筑寸ることを目的とし、シ ステムの基本構成のあり方の明確化、システムの試作、運用改善と
いった一連の調査研究、技術開発等を進めていこうとするものであ る。このようなシステムの実現のためには、対象となる教育研究資 源に関する情報の整備が大前提となり、モノや作業スペース等を有 効利用するには、柔軟な対応が可能な情報技術(IT)の活用が不可欠 である。本研究は作業環境に関するデータベースの構筑を通じて、 大学における教育研究に関する作業能率の向上を目指すものであり、 データベース管理システム(DBMS)の構築事例として位置づけられる。 大学での実用を目指す情報検索システム椣築のためには、利用 者が、どのような問題点を抱え、どのような情報を必要としている のかを十分に把暒し、それらをデータベースに反映させることが必 要である。また、大学には特定のシステム管理者がいないことやパ ソコンに不慣れな利用者もいることを考慮し、構築した情報検索シ ステムは、操作やメンテナンスが容易にできることが重要である。

本報は一連の研究の初段階をとりまとめたものであり、特に研 究内容が多分野にわたり、卒業研究も各個人がテーマを設定し、研 究または制作の選択が可能である本学工学部 工業デザイン学科を ケーススタディとし、現状のモ/や作業スペースの利用状況、それ らを利用する際の情報の入手先、問題点やその対処方法などをアン ケートにより調査分析し、作業鱑境に関する効果的なデータベース を構筑するための要件を明確化することを主たる目的とする。

\footnotetext{
* 千葉工業大学大学院工学研究科工業デザイン学専攻 工修

Graduate Student, Dept. of Industrial Design, Chiba Institute of Technology,

**千葉工業大学工学部工業デザイン学科 助教授・工博 


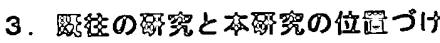

大学施設に関する研究自体は近年数多くされている。それらの 中で、関遉する論文をみてみると、谷口汎邦他 $(1990 \sim 1992)(1) \sim(5)$ では、学科が管理し、学生・教官が共通に使用する諸室の学科別に おける総面㭥の分布や用途別の室保有状況、同一室内における用途 の混在状況などを調㚗し、各スペースの图窮度の把握や研究組織単 位の保有面䅡の把握、用途別の使用室数、保有面筧の実態の明確化、 用途別の室における不足度の把握、满義室の利用状況・実績率と室 規模・学部規模との関係の把握などいずれも面積を中心とした調㚗 が行われている。これは様々な貔点からみた室面䅡についての現状 把握や、面裂に関しての問題点の明確化にとどまり、それ以外の問 題点や問題点に対する利用者の対処方法については触れていない。

また、谷口沉邦他（1992～1993）(の〜クでは、建築·土木系学科と 機站・電気・化学系学科の実験室の規模問題に着目し、個人および設 圈されている実鈳装圈の占有面積の把挃をしているが、これも参考 文献(1)〜(5)同様に面穦に関する問題点の明確化にとどまり、利用 者が抱える問題点や問題の対処方法については虽れられていない。

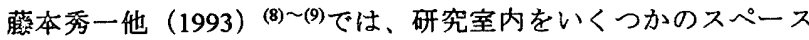
に分䫝し、研究室の在簛率、各スペース利用率や作業内容について 調㚗分析を行っている。その 2 では、各場所での作業時間を調㚗分 析し、利用者の状況に応じて、個人の領域が変化することを導いて いる。これは、研究室の中での作業内容や、滞在時間などから室内 のレイアウトの榆討をしていくものであり、研究室以外の部屋やモ ノについては考慮されていない。

和田悟他(1990) ${ }^{(10)}$ では、一般に高等教育施設になるほど請義室、 実習室などの単位空間は専門分化していく傾向にあるが、授業が単 一の活動だけで進行することは少なく、専門分化したスペースは使 いづらいと言う䂓点から、実習スペースの計画の指針を得るために、 短期大学における実習活租をケーススタディとして取り上げ、問題 点を把握しようとしたものである。一つの実習室の中での作業姿勢 や行動を調㚗し、空間内の物理的環境と人の行動の関係を把握して いるが、これは任意の授業で利用する一つの実習室の使われ方を把 提したものであり、利用者の個別の作業内容や、作業スペース別に よる違いなどには䖝れられていない。

以上のように関連諸研究は、学科が管理する保有面櫴や室数の 調㚗分析、学科別にみた特定の実跧室の規模に関する調㚗分析など、 面檞を問題点の中心に举げて調㿽分析されたもの、研究室内を作業 スペースで類別し、それぞれ作業内容や滞在時間を調㚗分析し、レ イアウトへの適用を試みるもの、一つの実習室での作業姿勢や行動 を調睢分析したものなどである。いずれも実際の面穦測定や行動観 察が中心である。学科が保有する主な作業スペース全体を対象とし、 利用者がその作業スペースや物品を利用する前に、それらの情報が どのように利用者に伝わったのか、また、利用の際に利用者自身が どのような問題点を抱え、それにどう対応しているのかなど、本調 亘研究が意図寸る調㸖分析を系統的に行った研究、調㚗結果をデー タベース權築の要件として用いた研究などは報告されていない。

\section{Q. 畾究の汸济}

F M 指向のデータベースの楬築には情報処理上の問題点の明確化 と処理対象となるべき资源情報の見極めが必要であり、ヒアリング
をもとにした尌前調㚗を受けて第一次アンケート調㚗（調㚗 1 ）を 行い、その結果明らかになった問題点等を蹬まえてより哨維な第二 次アンケート調㿽（調㚗 2 ）を実施し、結果の分析に結びつける手 順をとった。

面䅡規模やレイアウト関連調㿽は既往研究が多いため今回の検 討対象とはせず、利用する室空間、モノ、時間等を主対象に、利用 状況と問題点、所要属性、所要情報の確定過程の明確化等を狙いと してアンケート項目の検討を行った。アンケートは対象が限定され ているために調育員が直接手渡し、その主旨等を説明したうえで短 期に回収する配表調㚗とし、選択肢を主体に橑成することとした。 本研究で開発される卒研支援システムは学部学生ならびに院生、 指導教員が主たるユーザーとなると考えられるため、包括的現状把 握を目的とするべき調㚗 1 は本学工業デザイン学科 4 年生を、また 情報処理の流れなど、精維な分析を狙いとする調㚗 2 はより経験を 積んだ本学工業デザイン学専攻大学院生を对象に行うこととした。 また、工業デザイン系学科の特色としての設計・制作、実臨、 調査といった卒研テーマならびに所要作業の多様性、その多様性に 対処するための多目的な演習室、特定用途実験室等の活用度の如何 等も調㸖分析上の主たる項目とした。（注：これら諸室については その概要を表 1 内に示す。）

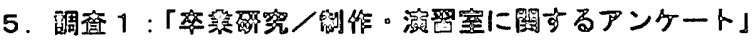

\section{$5-1$, 调㿽目的}

調㚗 1 の主目的は卒研支援のためのデータベースの基本權成や所 要譏能を明確化するための要件等の整理分析であり、4 年生が卒研 （卒業研究・制作）を行う際に使用した部屋やモノについて調㿽分 析し、実際の利用状況が示されることになる。また、本学科では 4 年生の卒研作業スペースとして多目的な演習室が研究室単位で区画 されたかたちで充当されており、この種の演習室の遥用形態のあり 方を探るための分析も主たる検討項目の一つとなっている。

\section{$5-2$. 酷条继要}

1)調㚗実施日：平成9年2月（卒業研究・制作終了時）

2)調公方法 : 配表調㚗（ほとんどが選択肢による回答）

3)調监対象：本学工業デザイン学科4年生 93人（回答率 100\%) (93人中研究中心が37人、制作中心が56人)

4)調㚗内容

・各作業スペースにおける作業内容

・モノを利用した場所

・モノを利用するときに图ったこととその对処方法

・作業スペースを利用するときに图ったこととその対処方法

・演習室の利用恢度

・演習室の利用目的

・演習室を利用しない場合のその理由

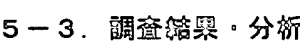

調蓇 1 の調㚗結果は表 1 ～8のとおりである。各スペースで行わ れる作業は、ほとんどのスペースで用途に合っている場合が多い。 研究室では、ワープロ・パソコンによる文書作成作業が多いが、こ れは链の管理がしっかりしており、パソコンの設置がされているか らであると考えられる。逆に演習室では、邀の管理などの問題から パソコンの設置が難しく、文畵作成は等記になることが多い。 
ほとんどのスペースが本来の用途に応じた使われ方をされる中で、 材料実験室のように本来の用途以外の作業にも万遍なく使われてい る場合があることも分かる。これは、当該所管研究室の学生が、実 験室を演習室（個人的なスペース）の代わりに利用し、あえて作業 ごとにスペースを使い分けようとしないからであると考えられる。

また顕著な結果として、学生の作業の中心は自宅になっている ことが分かる。これは、最近の価格低下によって個人のパソコン所 有率が高くなりつつあることや、授業やゼミなど決められた時間以 外に大学には来ない習慣がそうさせていると考えられる。自宅では 出来ない作業や、使えない道具を使う場合にのみ大学の設備を利用 する傾向にある。(表 1)

最低限必要に迫られた時のみ大学の施設を使うため、利用の際 の問題点として、「特に困ったことは無い」という回答も多いが、 一方で「何処にあるか分からない」といったもっとも基本的な情報 が不足していたり、どんなモノがあって、それが何のために使える のかという情報が無いために、「自分の行う行為に対して有効なモ ノが分からないといった回答も多い。また困ったことがあったと きは、「自分で考えて行動する」よりも「教員や大学院生に閏く」 というように、情報を持っている人に頼ることが多い。（表 2〜5） 演習室の利用頻度を分野別に見てみると、「ほぼ毎日」利用して いるのは、「実験」を中心に作業している学生だけである。これは、 実験を計画の段階から大学で作業を継続的に行っているからである。

表 1 . 各スペースで行った作業内容

\begin{tabular}{|c|c|c|c|c|c|c|c|c|c|}
\hline & & 実騃 & $\begin{array}{l}\text { 設計・ } \\
\text { 作図 }\end{array}$ & $\begin{array}{l}\text { I作 } \\
\text { 作業 }\end{array}$ & 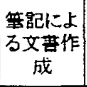 & 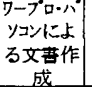 & $\begin{array}{c}\text { 分析·解 } \\
\text { 析 }\end{array}$ & 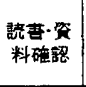 & その他 \\
\hline \multirow{3}{*}{ 研究室 } & 研究 & 0 & 0 & 0 & 12 & 12 & 12 & 18 & 8 \\
\hline & 制作 & 0 & 8 & 3 & 10 & 23 & 1 & 8 & 5 \\
\hline & \multicolumn{9}{|c|}{ 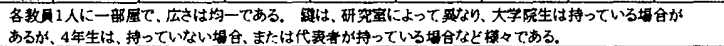 } \\
\hline \multirow{3}{*}{ 贫習室 } & 研究 & 1 & 4 & 5 & 15 & \begin{tabular}{|l|l|}
8 \\
\end{tabular} & 14 & 17 & 3 \\
\hline & 制作 & 0 & 13 & 14 & 6 & 2 & 1 & 9 & 2 \\
\hline & \multicolumn{9}{|c|}{ 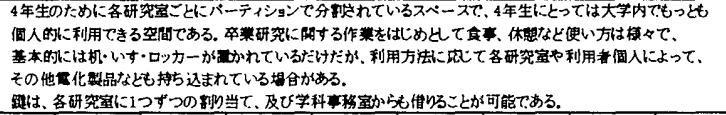 } \\
\hline \multirow{3}{*}{ CG室 } & 研究 & 1 & 0 & 2 & 0 & 2 & 1 & 0 & 4 \\
\hline & 制作 & 0 & 1 & 0 & 0 & \begin{tabular}{|l|}
9 \\
\end{tabular} & 1 & 0 & 8 \\
\hline & \multicolumn{9}{|c|}{ 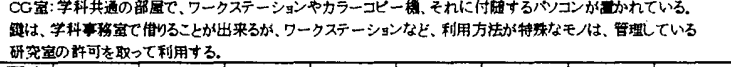 } \\
\hline \multirow{3}{*}{$\begin{array}{l}\text { 人閏工学 } \\
\text { 实駼室 }\end{array}$} & 研究 & 6 & 1 & 4 & 1 & 3 & 4 & 1 & 0 \\
\hline & 制作 & 0 & 0 & 0 & 0 & \begin{tabular}{|l|}
0 \\
\end{tabular} & 0 & 0 & 1 \\
\hline & \multicolumn{9}{|c|}{ 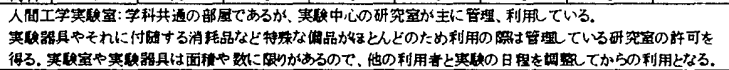 } \\
\hline \multirow{3}{*}{$\begin{array}{l}\text { AV- } \\
\text { ROOM }\end{array}$} & 研究 & 2 & 1 & 2 & 0 & \begin{tabular}{l|}
0 \\
\end{tabular} & 1 & 0 & 1 \\
\hline & 制作 & 0 & 0 & 0 & 0 & 0 & 0 & 0 & 0 \\
\hline & \multicolumn{9}{|c|}{ 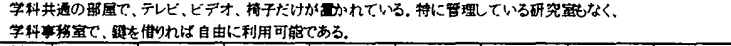 } \\
\hline \multirow{3}{*}{ 㷊料 } & 研究 & 3 & 0 & 2 & 2 & \begin{tabular}{l|}
1 \\
\end{tabular} & 3 & 1 & 0 \\
\hline & 制作 & 0 & 3 & 3 & 2 & 0 & 0 & 0 & 0 \\
\hline & \multicolumn{9}{|c|}{ 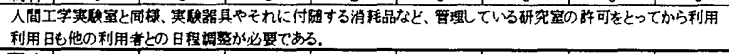 } \\
\hline \multirow{3}{*}{ 工作室 } & 研究 & 0 & 0 & 3 & 0 & 0 & 0 & 0 & 0 \\
\hline & 制作 & 1 & 1 & 10 & 1 & \begin{tabular}{l|}
0 \\
\end{tabular} & 2 & 1 & 0 \\
\hline & \multicolumn{9}{|c|}{ 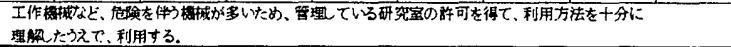 } \\
\hline \multirow{3}{*}{ 図茾館 } & 研究 & 0 & 0 & 0 & 3 & \begin{tabular}{|l|}
0 \\
\end{tabular} & 1 & 22 & 0 \\
\hline & 制作 & & & & 3 & 1 & 0 & 28 & 0 \\
\hline & \multicolumn{9}{|c|}{ 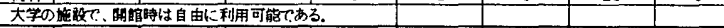 } \\
\hline \multirow{3}{*}{ 雹算室 } & 研究 & 0 & 0 & 0 & 0 & 0 & 0 & 1 & 1 \\
\hline & & & & & 0 & 0 & 0 & 2 & 3 \\
\hline & \multirow{2}{*}{\multicolumn{9}{|c|}{ 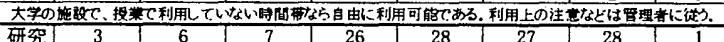 }} \\
\hline \multirow{2}{*}{ 自宅 } & 研究 & & & & 26 & 28 & 27 & 28 & 1 \\
\hline & 制作 & 6 & 43 & 29 & 33 & 36 & 16 & 37 & \\
\hline
\end{tabular}

表 2.モノを利用する際の問題点

\begin{tabular}{|c|c|c|c|c|c|c|}
\hline & $\begin{array}{l}\text { 特に困った } \\
\text { とは無かった }\end{array}$ & $\begin{array}{c}\text { 必要なモ/が } \\
\text { 何処にあるか } \\
\text { 分からなかか } \\
\text { た }\end{array}$ & 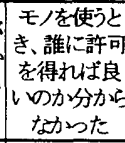 & $\begin{array}{l}\text { モノの使用方 } \\
\text { 法がからから } \\
\text { からた }\end{array}$ & 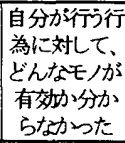 & その他 \\
\hline 研究 & 12 & 12 & 7 & 6 & 6 & 2 \\
\hline 制作 & 22 & 10 & 5 & 14 & 10 & 5 \\
\hline
\end{tabular}

表 3.モノに関する問題点の対処方法

\begin{tabular}{|c|c|c|c|c|c|c|}
\hline & 1人で考え行 & 先生に閒いた & 院生に䦥いた & 友達に開いた & あきらめた & その他 \\
\hline 研究 & 5 & 16 & 14 & 10 & 0 & 2 \\
\hline 制作 & 9 & 15 & 10 & 17 & 6 & 2 \\
\hline
\end{tabular}

表4. 場所を利用する際の問題点

\begin{tabular}{|c|c|c|c|c|c|c|}
\hline & $\begin{array}{c}\text { 困ったことは無 } \\
\text { かった }\end{array}$ & 鍵の管理 & $\begin{array}{c}\text { 必要なモかが } \\
\text { 無い }\end{array}$ & モノが使えない & 狭い & その他 \\
\hline 研究 & 14 & 6 & 3 & 2 & 9 & 1 \\
\hline 制作 & 24 & 13 & 16 & 6 & 10 & 5 \\
\hline
\end{tabular}

表5. 場所に関する問題点の対処方法

\begin{tabular}{|c|c|c|c|c|c|c|}
\hline & $\begin{array}{c}\text { 1人で考え行 } \\
\text { 動した }\end{array}$ & 先生に開いた & 院生に䦥いた & 友逵に開いた & あきらめた & その他 \\
\hline 研究 & 2 & 8 & 11 & 8 & 5 & 1 \\
\hline 制作 & 5 & 9 & 8 & 10 & 13 & 4 \\
\hline
\end{tabular}

表6. 演習室の利用頻度

\begin{tabular}{|c|c|c|c|c|c|}
\hline & グラフイック & プロダクト & 研究 & 実咉 & 設計 \\
\hline ほほ毎日 & 0 & 0 & 0 & 2 & 0 \\
\hline 1年を通して数回 & 4 & 3 & 8 & 10 & 10 \\
\hline ある一定期間内 & 3 & 9 & 5 & 9 & 9 \\
\hline 全く利用しない & 2 & 11 & 3 & 0 & 4 \\
\hline
\end{tabular}

表7. 演習室の利用目的

\begin{tabular}{|c|c|c|c|c|c|c|c|c|c|c|c|c|c|c|}
\hline & 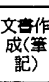 & 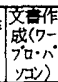 & 実衡 & 工作作 & 分折. & 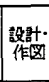 & 讜吉 & 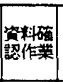 & 语查 & 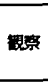 & 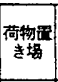 & 舕铦 & 休想 & 千の他 \\
\hline 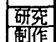 & \begin{tabular}{|l|}
18 \\
12
\end{tabular} & \begin{tabular}{|l|l|}
6 \\
\end{tabular} & $\frac{1}{0}$ & $\frac{5}{19}$ & 13 & $\frac{2}{12}$ & $\frac{12}{7}$ & $\frac{16}{10}$ & 0 & 0 & $\frac{12}{27}$ & $\frac{19}{24}$ & $\frac{18}{21}$ & $\frac{6}{5}$ \\
\hline
\end{tabular}

表8. 演習室を利用しない理由

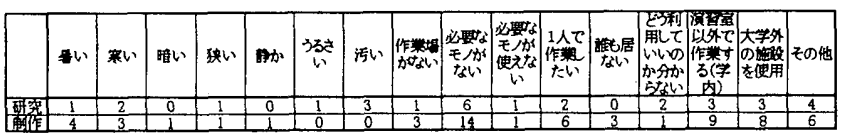

一方、プロダクト系では、「全く利用しない」とする学生がもっ とも多い(「全く利用しない」学生の55\%を占める)。出来る作業は 自宅で、工作機械などを必要とする作業などは工作室で行っている と考えることができる。（表 6 )

演習室の利用目的をみると、「荷物置き」「談話」「休㿞」といっ た直接的な作業ではないことで利用されている。そこで、利用しな い理由をみると、「必要なモノが無い」という回答がもっとも多い (21\%)。つまり、学生にとっての大学は、友達とのコミュニケーシ ヨンの場としての役割が大きく、施設面では、自宅では出来ない作 業や大学にしか無い設備を利用するだけにとどまり、作業の中心は 自宅であることが分かる。（表 $7,8 ）$

\section{6. 調査 2 :「モノ・場所利用に関するアンケート」}

\section{$6-1$. 調查目的}

調査 2 の主たる目的は、学生に比して、より主体性が高いと想定 される大学院生を対象に、研究および制作を進めていくうえで、部 屋やモノに関する情報の入手経路や入手時期、利用にあたっての問 題点とその対処方法について具体的な調查分析を行い、より現状に 則した実用的なデータベース構築のための各情報項目及びその関連 内容を決定することである。

\section{$6-2$. 調查概要}

1) 調査実施日：平成10年4月

2)調查方法 : 配表調查（ほとんどが選択肢による回答）

3) 調查対象：本学工業デザイン学専攻大学院生 25 人（回答率 $100 \%$ ) 4) 調查内容 :

・利用したモノの存在を何からいつ知ったか

-モノを利用する際の問題点、その対処方法と対処結果

- 利用した場所の存在を何からいつ知ったか

- 場所を利用する際の問題点、その対処方法と対処結果 


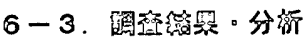

モノの存在を知るのは主に 4 年生の時であることが分かる。場所 の存在は「授業で使ったことがある」という回答例にも示されてい るように、3 年生からの場合む多いが、モノの場合は「授業で使っ たことがある」という回答は無く、基本的には、卒叢研究・制作に 取り組んでから改めて情報を得ることになる。また、4年生のころ は「自分の研究室の教員に閣く」ことが多いが、大学院 1 年目にな ると「自分の研究室の院生に閳く」方が多くなる。これは大学院生 同士の情報交换がより活発に行われているからだと考えられる。

表 9. 利用したモノを知った時期と情報源

\begin{tabular}{|c|c|c|c|c|c|c|}
\hline & 3年生以前 & 4年生 & 大学院 1 年目 & 大学院2年目 & $\begin{array}{c}\text { 大学院了年同 } \\
\text { 以降 }\end{array}$ & 計 \\
\hline 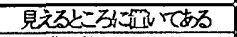 & 1 & 9 & 6 & 3 & 0 & 19 \\
\hline 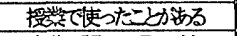 & 0 & 0 & 0 & 0 & 0 & 0 \\
\hline 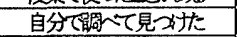 & 0 & 1 & 1 & 0 & 0 & 2 \\
\hline 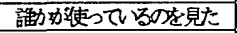 & 3 & 3 & 0 & 0 & 0 & 6 \\
\hline 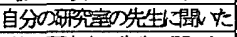 & 1 & 5 & 1 & 1 & 0 & 8 \\
\hline 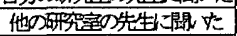 & 0 & 0 & 0 & 0 & 0 & 0 \\
\hline 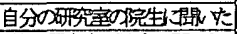 & 0 & 2 & 7 & 2 & 0 & 11 \\
\hline 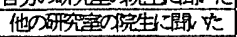 & 0 & 0 & 0 & 0 & 0 & 0 \\
\hline zosit & 2 & 2 & 1 & 1 & 0 & 6 \\
\hline 敦 & 7 & 22 & 16 & 7 & 0 & \\
\hline
\end{tabular}

表10.利用した場所を知った時期と情報源

\begin{tabular}{|c|c|c|c|c|c|c|}
\hline & 3年生以前 & 4年生 & 大学院1年 & 大学完2年目 & 大学䄈年 & 郭 \\
\hline 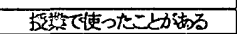 & 3 & 3 & 0 & 0 & \begin{tabular}{|l|l|}
1 \\
\end{tabular} & \\
\hline 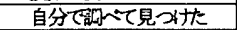 & 6 & 1 & 0 & 0 & 0 & 7 \\
\hline 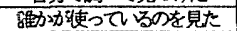 & 0 & 2 & 0 & 0 & 0 & \\
\hline 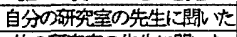 & 2 & 6 & 2 & 1 & 1 & 12 \\
\hline 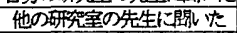 & 1 & 0 & 0 & 0 & 0 & \\
\hline 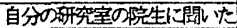 & 2 & 1 & 7 & 0 & 0 & 10 \\
\hline 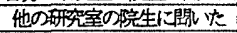 & 0 & 1 & 0 & 0 & 0 & \\
\hline 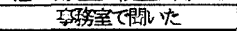 & 0 & 4 & 2 & 0 & 0 & 6 \\
\hline of & 14 & 18 & $\overline{11}$ & 1 & $\overline{2}$ & \\
\hline
\end{tabular}

表11.利用したモ/別の問題点とその対処方法

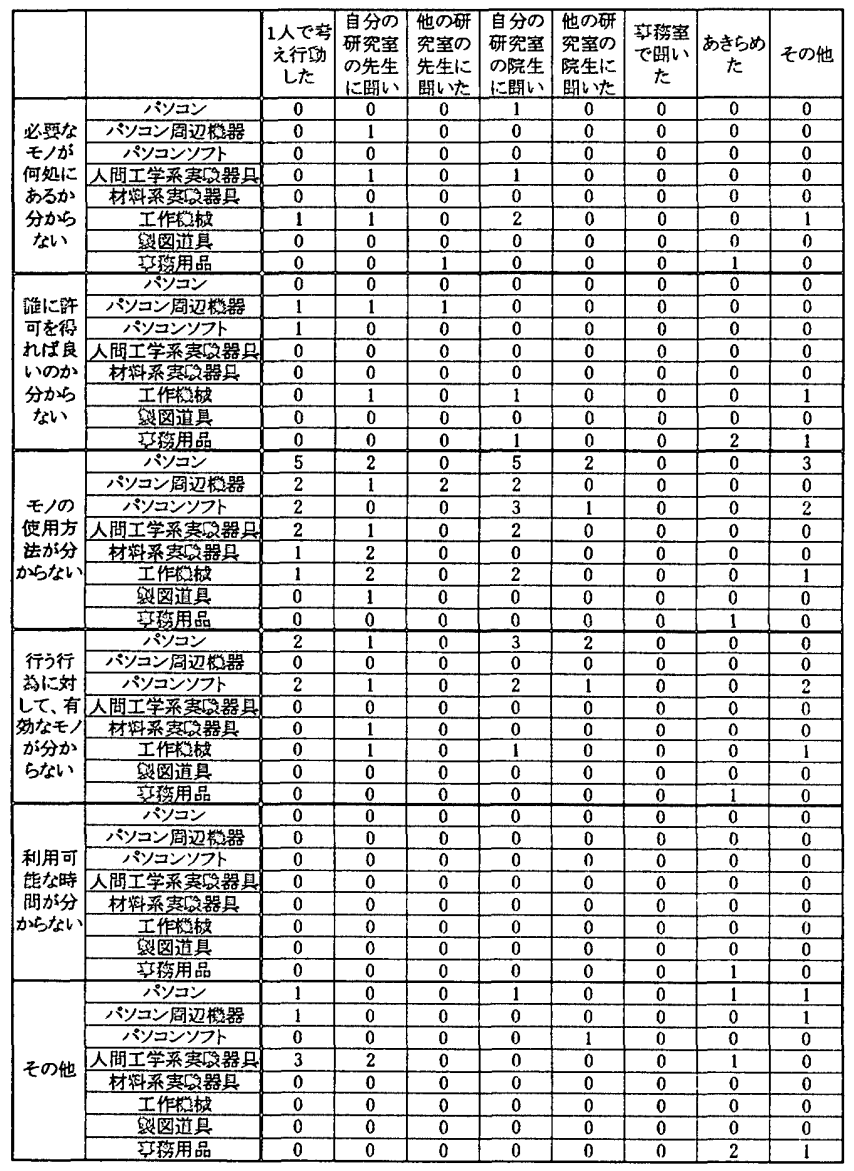

一方で、「他の研究室の教員」や「他の研究室の院生」から閣く ことはほとんど無く、たいていの場合、自分の研究室内だけで、情 報が伝達されることが分かる。（表 9、10）

利用したモノに関わる問題点としてはモノ自体の「使用方法が分 からない」「自分が行う行為に対して有効なモノが分からない」 といった、そのモノが何の為をするためのモノなのか、どのように 使うのかといった基本的な情報が得られてないことがあげられる。 モノを利用して問題点があった場合、ほとんどのモノで「自分の研

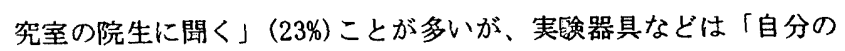
研究室の先生に㵎く」ことが多い。これは器具自体が㝶門的なモノ

表12. モノを利用した際の問題点に対する研究室別の対処方法

\begin{tabular}{|c|c|c|c|c|c|c|c|c|}
\hline & $\begin{array}{l}\text { 1人で考え } \\
\text { 行勘した }\end{array}$ & 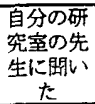 & $\begin{array}{l}\text { 他の研究 } \\
\text { 竟の先生 } \\
\text { に聞いた }\end{array}$ & $\begin{array}{c}\text { 盼分の研 } \\
\text { 空の院 } \\
\text { 生た閏い } \\
た\end{array}$ & \begin{tabular}{|l} 
他の研究 \\
室の院生 \\
に門いた
\end{tabular} & $\begin{array}{l}\text { 磑務室 } \\
\text { 間い }\end{array}$ & あきらめ & \\
\hline 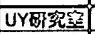 & 4 & 4 & 0 & 4 & 2 & 0 & 1 & 2 \\
\hline & 7 & 2 & 1 & 4 & 0 & & 1 & 2 \\
\hline TTER & 2 & 0 & 1 & 0 & 0 & 0 & 0 & 0 \\
\hline 究空 & 4 & 3 & 0 & 1 & & 0 & 0 & 0 \\
\hline 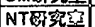 & 2 & 3 & 0 & 1 & 0 & 0 & 0 & 0 \\
\hline & 0 & 0 & 0 & 0 & 0 & 0 & 1 & 0 \\
\hline 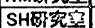 & 0 & 1 & 0 & 5 & 0 & 0 & 1 & \\
\hline & & 0 & 0 & & & 0 & 0 & \\
\hline
\end{tabular}

表13. モノを利用した際の問題点に対する出身校別の対処方法

\begin{tabular}{|c|c|c|c|c|c|c|c|c|}
\hline & $\begin{array}{l}1 \text { 人で帘え } \\
\text { 行施たた }\end{array}$ & 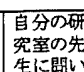 & 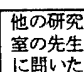 & 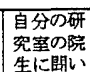 & 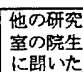 & 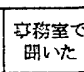 & あきらめた & その他 \\
\hline & & $\frac{11}{11}$ & 1 & 8 & 6 & 0 & 3 & 9 \\
\hline
\end{tabular}

表14. 利用した場所別の問題点とその対処方法

\begin{tabular}{|c|c|c|c|c|c|c|c|c|c|}
\hline & & $\begin{array}{l}\text { 1人て方 } \\
\text { 立行 } \\
\text { した }\end{array}$ & 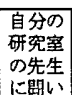 & 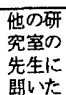 & 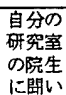 & $\begin{array}{l}\text { 他の研 } \\
\text { 究案の } \\
\text { 院生に } \\
\text { 活いた }\end{array}$ & 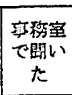 & $\begin{array}{c}\text { あきらめ } \\
た\end{array}$ & その他 \\
\hline \multirow{6}{*}{ 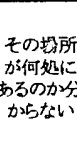 } & 研究室 & & & 0 & $\frac{2}{2}$ & & & 0 & 0 \\
\hline & 演習黨 & 0 & 0 & 0 & & 0 & 0 & & \\
\hline & 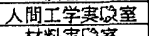 & 0 & 0 & 0 & 0 & 0 & 0 & $\frac{0}{0}$ & 0 \\
\hline & 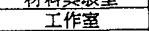 & 0 & 0 & 0 & 2 & 0 & & & \\
\hline & & 0 & 0 & 0 & 0 & & $\begin{array}{ll}0 \\
0\end{array}$ & $\begin{array}{l}0 \\
0\end{array}$ & 0 \\
\hline & $\frac{z \operatorname{coth}}{2}$ & 0 & 0 & 0 & 0 & 0 & 0 & 0 & 0 \\
\hline \multirow{5}{*}{ 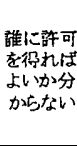 } & 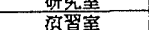 & & & 0 & $\frac{1}{0}$ & $\frac{0}{0}$ & 0 & 0 & \\
\hline & 人問工学责的室 & 0 & $\frac{0}{0}$ & $\frac{\sigma_{0}}{0}$ & 0 & & 0 & & \\
\hline & 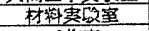 & $\begin{array}{lll}0 & \\
0\end{array}$ & 1 & 0 & 0 & $\overline{0}$ & 0 & 0 & 0 \\
\hline & 工作咅 & 1 & 0 & 0 & 2 & 0 & 0 & 0 & \\
\hline & 201害 & 0 & 0 & 0 & 0 & 0 & 0 & 0 & \\
\hline \multirow{5}{*}{ 辕の管理 } & 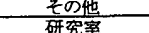 & $\frac{1}{0}$ & 1 & $\frac{0}{0}$ & $\frac{0}{3}$ & 0 & 0 & $\frac{0}{1}$ & $\frac{0}{2}$ \\
\hline & 沟習室 & 2 & 1 & 0 & 2 & 0 & 2 & 1 & 1 \\
\hline & 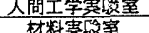 & $\frac{1}{0}$ & $\frac{2}{1}$ & $\frac{0}{0}$ & $\frac{1}{0}$ & $\frac{0}{0}$ & $\frac{0}{0}$ & $\frac{0}{0}$ & $\frac{0}{0}$ \\
\hline & & 1 & 0 & 1 & 0 & 0 & 0 & 0 & 0 \\
\hline & DLT & 0 & 0 & 0 & 0 & 0 & 0 & 0 & 0 \\
\hline \multirow{6}{*}{ 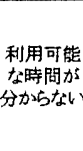 } & 研究室 & $\frac{1}{0}$ & $\frac{1}{2}$ & $\frac{0}{0}$ & $\frac{1}{1}$ & 0 & 0 & $\frac{1}{1}$ & $\frac{1}{1}$ \\
\hline & 负習害 & 1 & 1 & 0 & 1 & $\overline{0}_{0}$ & 1 & 1 & \\
\hline & 人問工学害路空 & 1 & 1 & 0 & $\frac{1}{1}$ & 0 & 0 & 0 & \\
\hline & 材料费的量 & 0 & 0 & 0 & 0 & 0 & 0 & 0 & \\
\hline & & & 0 & 0 & 0 & 0 & 0 & 0 & \\
\hline & 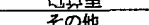 & 0 & 0 & 0 & 0 & 1 & 0 & 0 & 0 \\
\hline \multirow{6}{*}{ 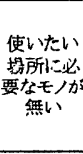 } & 研究裏 & 0 & 0 & 0 & 0 & 0 & 0 & 0 & 0 \\
\hline & & & 0 & 0 & $\frac{2}{3}+>$ & 0 & 0 & $\left.\frac{0}{n}+2\right)$ & 0 \\
\hline & 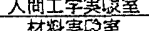 & 0 & 0 & 0 & 0 & $\frac{0}{n}+{ }_{0}$ & 0 & 0 & 0 \\
\hline & 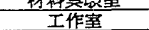 & $\frac{0}{1}$ & $\frac{0}{0}$ & 0 & $\frac{0}{1}$ & $\frac{0}{0}$ & 0 & $\frac{0}{0}$ & $\frac{0}{0}$ \\
\hline & 包等室 & 0 & 0 & 0 & 0 & 0 & 0 & 0 & \\
\hline & zos他 & 2 & $\frac{1}{1}$ & 0 & 0 & 0 & 0 & 1 & 0 \\
\hline \multirow{5}{*}{$\begin{array}{l}\text { 使いたい } \\
\text { 场所で必 } \\
\text { 㑮えなか }\end{array}$} & 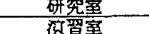 & $\frac{1}{2}$ & $\frac{2}{0}$ & $\frac{0}{0}$ & $\frac{2}{1}$ & $\frac{0}{0}$ & $\frac{0}{0}$ & $\frac{0}{0}$ & $\frac{0}{0}$ \\
\hline & 人問工学害卧室 & 0 & 0 & 0 & $\sigma_{0}$ & $\overline{0}$ & 0 & 0 & 0 \\
\hline & 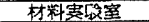 & 0 & 0 & 0 & 0 & 0 & 0 & 0 & 0 \\
\hline & I稚咅 & 1 & 0 & 0 & 1 & 0 & 0 & 0 & 0 \\
\hline & 然 & 0 & & & & & 0 & & 0 \\
\hline \multirow{6}{*}{ 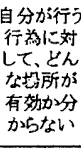 } & 研究咅 & $\frac{0}{0}$ & $\frac{0}{0}$ & 0 & $\frac{0}{1}$ & $\frac{0}{0}$ & $\frac{0}{0}$ & $\frac{0}{0}$ & 0 \\
\hline & & 0 & 0 & 0 & 0 & 0 & 0 & $\begin{array}{l}0 \\
0\end{array}$ & 0 \\
\hline & 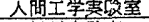 & 0 & 0 & 0 & 0 & 0 & 0 & 0 & 0 \\
\hline & 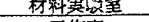 & 0 & 0 & $\underline{0}$ & 0 & 0 & 0 & 0 & 0 \\
\hline & 贡俈瑟 & 0 & 0 & 0 & 0 & 0 & 0 & 0 & 0 \\
\hline & 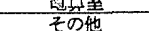 & $\frac{0}{0}$ & $\frac{0}{0}$ & $\frac{0}{0}$ & 0 & $\frac{1}{0}$ & $\frac{0}{0}$ & 0 & $\frac{0}{0}$ \\
\hline \multirow{5}{*}{ その他 } & 研究室 & 0 & $\frac{1}{1}$ & 0 & 1 & 0 & 0 & 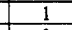 & 1 \\
\hline & 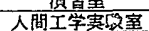 & $\frac{1}{1}$ & $\frac{0}{1}$ & 0 & $\frac{1}{0}$ & $\frac{0}{0}$ & $\frac{0}{0}$ & $\frac{0}{1}$ & \\
\hline & 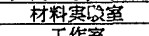 & 0 & $\frac{1}{0}$ & 0 & $\frac{1}{0}$ & 0 & 0 & $\frac{1}{0}$ & $\frac{0}{0}$ \\
\hline & & & & & 0 & $\frac{0}{0}$ & 0 & & \\
\hline & 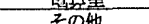 & $\frac{0}{2}$ & $\frac{0}{2}$ & 0 & 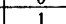 & 0 & 0 & 0 & 1 \\
\hline
\end{tabular}


表15. 場所を利用した際の問題点に対する研究室別の対処方法

\begin{tabular}{|c|c|c|c|c|c|c|c|c|}
\hline & $\begin{array}{l}1 \text { 人で考え } \\
\text { 行野した }\end{array}$ & $\begin{array}{l}\text { 自分の研 } \\
\text { 空の先 } \\
\text { 生に閏い } \\
た\end{array}$ & $\begin{array}{l}\text { 他の研究 } \\
\text { 空の先生開いた }\end{array}$ & \begin{tabular}{|c|} 
自分の研 \\
空の院 \\
生に䦥い \\
た \\
\end{tabular} & \begin{tabular}{|l|} 
他の研究 \\
至の院生 \\
に閶いた
\end{tabular} & 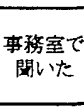 & $\begin{array}{c}\text { あきらめ } \\
\text { た }\end{array}$ & その他 \\
\hline UY研究音 & 3 & 5 & 1 & 3 & 1 & 0 & 1 & 0 \\
\hline & 4 & 2 & 0 & 3 & 0 & 0 & 0 & 0 \\
\hline & 0 & 1 & 0 & 1 & 0 & 0 & 0 & \\
\hline & 2 & 3 & 0 & 1 & 0 & 0 & 1 & 0 \\
\hline & 1 & 2 & 1 & 3 & 0 & 0 & 0 & 0 \\
\hline & 0 & 2 & 0 & 2 & 0 & 0 & 0 & 1 \\
\hline & 2 & 0 & 0 & 4 & 0 & 0 & 0 & \\
\hline & 2 & 0 & & & 0 & & 3 & \\
\hline
\end{tabular}

表16. 場所を利用した際の問題点に対する出身校別の対処方法

\begin{tabular}{|c|c|c|c|c|c|c|c|c|}
\hline & $\begin{array}{l}\text { 行考え } \\
\text { 行動した }\end{array}$ & 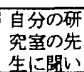 & 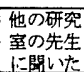 & 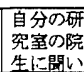 & 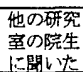 & 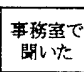 & あきらめた & その他 \\
\hline 本学出身 & 11 & 11 & thent & $\frac{1}{8}$ & $\frac{1}{1}$ & 3 & & 3 \\
\hline
\end{tabular}

であり、主に管理している教員の研究室の学生が利用することがほ とんどのためにその専門の教員に確認してから利用するためである。

一方、パソコンなど一般的なモノについては、自分の研究室の

教員に聞く」よりも普段からよく利用して分かっている「他の研究 室の院生に聞く」方が多い。また、S H 研究室とA T研究室は新た に着任された教員であるが、この場合は、大学院生を頼りにする傾 向が一層強くなる。出身校別にみると、本学出身の院生は「他の研 究室の院生に聞く」ことも多いが、他大学出身の院生に関しては、 それは全くない。(表11〜13)

利用した場所の問題点としては、「鍵の管理」がもっとも多い (27\%)。鍵の管理がはっきりしないために「利用可能な時間」(12\%) も問題点としてあがってくる。問題の対処方法もモノと同様に「自 分の研究室の院生に聞く」(29\%)や「自分の研究室の先生に聞く」 (24\%) といった回答が中心である。場所の問題で「他の研究室の先 生に聞く」(3\%)ことがほとんど無いと言うことは、主に自分の研究 室の先生が管理している場所しか利用していないと考えられる。

問題の対処方法としては、モノの場合同様に「自分の研究室の先 生に聞く」と「自分の研究室の院生に聞く」ことが多いが、問題の 対処方法としては、「他の研究室の院生に聞く」(2\%)ことはほとん どない。A T研究室では「事務室で聞く」こともあるが、同時にあ きらめてしまうケースも他の研究室に比べて多い。出身校别にみて も、やはりモノの対処方法と同様に他大学出身の院生は、「自分の 研究室の院生に聞く」.ことが中心であることが分かる。(表14〜16)

\section{7.まとめ}

4 年生が卒業研究・制作に関する作業を進めるうえで、モノや 作業場所に関して「何が」「何処にあるか」「どのように使うのか」 などの基本的な情報が行き届いていないこと、作業場所の中心はあ くまでも自宅に集中し、大学の施設の利用頻度が低いことが明確に なった。これは作業の中心が大学ではないために、いざ大学のモノ や作業場所を使おうとしたときに基本的な情報が行き届いていない ということになる。

また、多くの学生は 4 年生の時点で卒業研究・制作を進行して いる最中に大学の設備に関する様々な情報を得るため、それを継承 する唯一の存在として、大学院生が重要な役割を果たしていること も明確になったが、他大学出身の大学院生にとっては他研究室の大 学院生との情報交換が難しく、所属研究室以外で管理しているモ， や場所に関する情報が得にくいという問題も存在する。

以上の調查から、大学のモノや作業場所に関するデータベースを
構築し、それを学生が自由に利用できるようにすることは、卒業研 究・制作を進めていくうえで有効であると考えられる。

データベースの内容として、各備品については、名称・保管場所・ 管理責任者·用途など、各作業場所については、部屋の名称・配置図・ 管理責任者·键の管理状況·設置されている設備·可能な作業内容な どをまとめ、自分が行う行為に対する有効なモノが分かるように、

「設計」「実験」「分析・解析」など行う行為から関連するモノや作 業場所が分かるようにすべきこと、情報検索における使用方法も、 基本的に大学には大学院生外に情報を継承する人間が居ないことや、 そのデータベースに専門の管理者が存在しないことを考慮し、使い 方も分かりやすく、データの更新もしやすいものを目指寸必要があ ることなどが明確となった。

今後はこれらのことを考慮し、調查結果をもとに、研究・制作の 作業効率を向上させるためのデータベース構筑を進めていく。

\section{参考文献}

（1）望月一正 高野文雄 谷口汎邦 山口勝巳 海老沼修: 国立大学工科系 学部における学科共通室の規模・室構成一国立大学学部校舎の建策計画に関

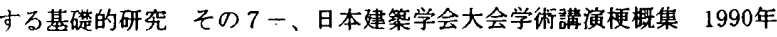
(2) 高野文雄 谷口汎邦山口勝巳 海老沼修: 国立大学工科系学部におけ る研究組織単位の所属人数と保有面皘一国立大学学部校舎の建策計画に関す る基磁的研究 その 8 -、日本建策学会大会学術講演梗概集 1990 年 （3）海老沼修 高野文雄 谷口沉邦山口勝巳: 国立大学工科系学部におけ る研究組織単位使用室の室構成と利用状況一国立大学学部校舎の建築計画に 関する基磽的研究 その 9 -、日本建策学会大会学術講演梗概集 1990 年 （4）高野文雄 谷口汎邦山口勝巳：国立大学工科系学部における研究組䋨 单位使用室に対する評価一国立大学学部校舎の建策計画に関する基䃈的研究 その10-、日本建筑学会大会学術譜演梗概集 1991 年

（5）谷口汎邦 高野文雄 山口勝已 大屋三幸: 国立大学工科系学部におけ る捧義室の規模・室糊成と利用状况一国立大学学部校舍の建筑計画に関する 基䃈的研究 その11-、日本建策学会大会学術講演梗概集 1992年 （6）谷口汎邦 高野文雄 山口勝已 浦田尚志 石田有作 丸野道明：大学 工学系学部建筑・土木系学科の実験室規模標潅について一大学工学系学部規 模計画に関する基䃈的研究 その1、その2-、日本建築学会大会学術講演梗 概集 1992 年

（7）谷口汎邦 高野文雄 山口勝巳 石田有作 松田雅司：大学工学系学部 機械・電気・化学系学科の実験宝規模標淮について一大学工学系学部規模計 画に関する基䃈的研究 その3、その4一、日本建策学会大会学術軿演梗概集 1993年

（8）藤本秀一 翼和夫 高田光雄 毛谷村英治：大学研究空の境境整偏に関 する基碮的研究一その1．実熊調查による研究室の使われ方とその問題点の 把握、日本建策学会大会学術講演梗概集 1993 年

（9）山田哲弥 井上誠 惼村仁志 藤本秀一：大学研究室の慗境整偏に関す る基整的研究一その2．研究室に㧍ける各執務者の領域性 日本建築学会大 会学術講演梗概集 1993 年

（10）和田悟 柳澤忠 志水暎子 鉿木㹂一：短期大学における実習スペー スの計画に関する研究、日本建策学会大会学術講演梗概集 1990年

（11）高野文雄 谷口汎邦山口勝已 石田有作：国立大学工科系学部に おける研究組織単位の人的權成と使用面積の特性一国立大学工科系学部の施 設計画に関する研究 その1、日本建築学会計画系論文集 1996年7月 （1999年 9 月 9 日原稿受理，1999年11月18日採用決定） 